\title{
Adaptation of Positive Mental Health Scale into Turkish: A Validity and Reliability Study ${ }^{1}$
}

\author{
Aynur Yılmaz Akbaba ${ }^{2}$
}

Jale Eldeleklioğlu ${ }^{3}$

\begin{abstract}
In this paper, it was aimed to adapt the Positive Mental Health Scale (PMHS) into Turkish language. In total 360 university students with ages ranging from 18 to 25, participated in the research. Validity and reliability analysis were carried out after the linguistic equivalency of the scale was examined. The psychometric properties of the scale were examined by internal consistency, exploratory and Confirmatory Factor Analysis, it comes in view that the scale has a single factor structure. Related to the PMHS, the internal consistency coefficient was found .85. In the context of the criterion-related validity, positive correlations were found between Positive Mental Health Scale (PMHS) and Oxford Happiness Questionnaire (OHQ), Psychological Well-being Scale (PWS) and Brief Resilience Scale (BRS). It is concluded that the PMHS is a valid and reliable instrument to measure positive mental health level of university students.
\end{abstract}

Keywords: Positive Mental Health, Psychological Well-Being, Validity, Reliability

\section{INTRODUCTION}

Previous studies on mental health were mostly focusing on adverse elements of psychology such as health problems, psychopathology and psychiatric disorders. Aside from these adverse elements of mental health, some positive elements including satisfaction with life, social support, self-respect, durability and happiness are also chosen as a subject by contemporary studies of recent years. These positive elements of mental health are also emphasized in the World Health Organisation's definition of health while the notion of being healthy was defined as being in a state of physical, mental and social well-being completely; not solely as being not sick or the absent of strength (WHO, 2003). Hence, it is not sufficient to define mental health through not having mental sickness or psychopathology.

The well-being notion grounds on two traditional approaches. These are hedonic and eudaimonic approaches (Ryan \& Deci, 2001; Waterman, 1993). Hedonic (subjective) well-being symbolizes happiness, satisfaction and being attached to life (Diener, 2000) while the eudaimonic (psychological) well-being involves self-realization and being completely operational (Ryff, 1989). Ryff identifies the positive elements of functionality by synthesizing the current well-being literature. On this matter, Ryff (1989) presents a well-being model consisting of six dimensions, which are; self-acceptance, establishment of quality ties to other, a sense of autonomy, the ability to control complex environments, sense of purpose in life and personal development. Via his model, Ryff emphasizes the individual's struggle to achieve perfection and develop his/her potential to an optimally functional level (Ryff, 1995). When these two approaches are taken into consideration in unison, positive mental health is identified

\footnotetext{
1 Submitted in 2nd Eurasian Congress on Positive Psychology, İstanbul, 12-14 May 2017.

2 Doctorate student, Bursa Uludağ University, Institute of Educational Science, fanuryilmaz@gmail.com, Bursa/Turkey

3 Prof. Dr., Bursa Uludağ University, Fakulty of Education, eldelek@uludag.edu.tr, Bursa/Turkey
} 
as the general existence of emotional, psychological and social well-being (Keyes, Shmotkin, \& Ryff, 2002).

Individuals that have positive mental health or well-being are known to settle consistent relations, have purpose for life, are capable to have mostly positive affection and self-acceptance (Keyes, 2002; Ryan \& Deci, 2001), have social and coping skills, are inclined to give and take emotional support, maintain personal development and autonomy, join religious and spiritual practices (Vaingankar et al., 2012). Additionally, in a study on preventive factors and risk factors as the predictors of incidence, remission and relapse of axis 1 mental disorders by Lukat, Becker, Lavallee, van der Veld, \& Margraf, (2017), it is concluded that the positive mental health, perceived as one of the preventive factors, is an important factor in predicting the remission period. Similarly, in another study done by Maercker et al., (2015) on social support and resilience as mediators in relationship between mental health and personal value orientations, it is determined that social support plays a mediating role for traditional values to predict mental health, while resilience is the mediator for modern values which predict the mental health.

Some assessment scales subjecting positive mental health has been found after a literature review. Most frequent one of these is determined to be the Well-Being Scales developed by Ryff (1989). Furthermore, there are many scales used to measure mental health, such as Scale of Psychological Well-Being (Diener et al., 2009), The Warwick-Edinburgh Mental Well Being Scale (Tennant et al., 2007), Satisfaction With Life Scale (Diener, Emmons, Larsen, \& Griffin, 1985), General Health Questionnaire (Hu, StewartBrown, Twigg, \& Weich, 2007). However, considering its holistic approach, Positive Mental Health Scale had been developed by Lukat, Margraf, Lutz, van der Veld, and Becker (2016) to contribute to the literature. The scale is a single-dimensioned self-report scale consisting of 9 items. Besides its holistic approach to positive mental health, it differs from other scales by its practices in assessing therapeutic effect and medical treatment. Its potential practice in both positive psychological researches and evaluating therapeutic effect and clinical applications, adapting Positive Mental Health Scale into Turkish is considered to contribute the literature. The purpose of this research is to adapt the positive mental health scale to Turkish and to examine its psychometric properties.

\section{METHOD}

\section{Study Group}

The study group consisted of 362 university students studying in Hacettepe University in 2017-2018 academic year. Two participants were removed from the study data for the reason of being counted as extreme value. Hence all analyses were carried out using the data collected from 360 participants. $80.3 \%$ of participants were women $(n=289)$ while $19.7 \%$ were men $(n=71)$. Participants included in study were consisting of students from the departments of psychological counseling and guidance, social service, political sciences, public administration and healthcare management. Mean value for age was 20.49 with a standard deviation of 2.32 . 


\section{Data Collection Tools}

\section{Positive Mental Health Scale (PMHS):}

Positive Mental Health Scale, developed by Lukat et al. (2016) consists of 9 items. The scale assesses the emotional aspects of well-being mostly without correlating it directly to well-being theories. The scale is developed for evaluating one holistic positive emotion notion related to mental health.

The items of PMHS includes Trierer Personality Inventory (Becker, 1989), Freiburg Personality Inventory (Fahrenberg, Selg, \& Hampel, 1989), Mental Health Scale (Tönnies, Plöhn, \& Krippendorf, 1996), The Bern Subjective Well-Being Questionnaire for Adolescents (Grob et al., 1991) and two new items developed by Lukat et al. (2016). These items belonging to PMHS are in 4-point Likert type with the order from 0 to 3 as (0) being not true and (3) being true. All items are expressed positively. A high score collected from the scale indicates high positive mental health. Development of the scale and validity-reliability analyses were realized through student and patient groups. Reliability of the scale was calculated using internal consistency and test-retest methods. Internal consistency-reliability coefficient was found to be ranging between the values of .84 to .93 . Furthermore, value for test-retest reliability co-efficient was .81. Relationships between the PMHS and other scales were investigated within the context of criterion-referenced validity. As a result; Positive Mental Health Scale and The Bern Subjective Well-Being Questionnaire for Adolescents had relationship value of $(r=.81)$ while Social Support Scale and PMHS had (.52). On the other hand, Depression, Anxiety and Stress Scale (Lovibond \& Lovibond, 1995) and Positive Mental Health Scale were found to correlate negatively for the subscales of depression $(r=-.74)$, anxiety $(r=-.51)$ and stress $(r=-.56)$. Adaptation of PMHS to other cultures has been carried out by Maercker et al. (2015). According to this adaptation study, reliability values were found to be .93 for German, .86 for Russian and .90 for Chinese.

\section{Psychological Well-Being Scale (PWBS)}

The psychological Well-Being Scale was developed by Diener et al. (2010) for assessing sociopsychological well-being and as a complementary scale to the existing ones. Adaptation of the scale was realized by Telef (2013). As a result of the Exploratory Factor Analysis, total explained variance was found to be $42 \%$. Weighting factor values of the items were calculated to be ranging between .54 and .76 . The scale includes 8 positive items. The lowest possible score is 8 , while the highest possible is 56 . A high score means that individual possesses many psychological strength and resources. Cronbach Alpha internal consistency coefficient of the scale is .85 .

\section{Oxford Happiness Questionnaire (OHQ)}

OHQ is a 6-point Likert type scale with 8 items, that is developed by Hills and Argyle (2002) for happiness level assessment. In the study involving the Turkish adaptation of the scale, carried out by Doğan and Çötok (2011), the research was delivered through 7-item variation of the scale; the fourth item was removed from the scale due to low item total correlation. Turkish version of the scale was designed in 5-point Likert type (1: Strongly Disagree - 5: Strongly Agree). While the first and the seventh items are negative statements; the lowest possible score to receive is 7, while the highest score available is 35. Mean score received is used for calculating individual's happiness level. Cronbach Alpha internal consistency coefficient of the scale was .68. 


\section{The Brief Resilience Scale (BRS)}

The scale is developed by Smith et al. (2008) with the aim of measuring the psychological resilience of the individuals. BRS is a 5-point Likert type scale with six items and in self-report style. Turkish adaptation of the scale was implemented by Doğan (2015). As a result of the explanatory factor analysis, total explained variance was found to be $54.66 \%$. Weighting factor values of the items were calculated to be ranging between .63 and .79. The reliability of the scale was evaluated via methods of internal consistency. Results indicate that the internal consistency coefficient value was .83. After reverse coding the negative items, higher total scores correspond to higher psychological resilience.

\section{Procedure}

Firstly, to adapt the scale into Turkish culture, the contact with Justina Lukat has been made through email and necessary permissions were obtained. Translation-retranslation method was used to achieve linguistic equivalence. Original form in English language was translated into Turkish with the cooperation of five senior psychology consultants. Researchers examined acquired translations and statements that were accepted to be the most explanatory were chosen. Acquired Turkish form was translated into the original language, English, by two experts in the area who had not seen the scale before. As a result, with the presupposition that translated form was equal to the original one, study proceeded to the implementation phase. After the participants were provided with necessary information, measuring instruments were applied in person. To examine the structural validity of the Positive Mental Health Scale (PMHS), criterion-referenced validity methods of Exploratory Factor Analysis (EFA), Confirmatory Factor Analysis (CFA) were used. Reliability of the scale is examined through item analysis, calculation of internal consistency coefficient and test-retest method. Analyses are realized via software; SPSS 20.

\section{FINDINGS}

\section{Exploratory Factor Analysis (EFA)}

EFA was implemented to specify scale's factor structure on Turkish university students. To achieve this, calculation of Kaiser-Meyer-Olkin (KMO) coefficient and Bartlett's Test of Sphericity were carried out to ensure factor analysis suitability of the data. For data to be suitable for factor analysis, Kaiser-MeyerOlkin (KMO) coefficient value needs to be higher than .60, while Bartlett Test needs to be found meaningful (Büyüköztürk, 2004). In this study, KMO value was .889 and Bartlett Sphericity Test $\chi 2$ value was $1232.254(p<.000)$. These results showed that the data was suitable for factor analysis and scores were distributed normally. As a result of the analysis without any rotation, a single-factor structure that explained the $48.466 \%$ of total variance was created. In single-factor scales, adequate value for variance explanation is accepted to be $30 \%$ (Büyüköztürk, 2002). Factor loadings concerning scale items were found to be ranging between .51 and .88. Detailed factor loadings are given below in Table 1 . 
Table 1.

The Factor Loadings Concerning Positive Mental Health Scale

\begin{tabular}{ll}
\hline Items & Factor Loading \\
\hline 1. I am often carefree and in good spirits. & .806 \\
2. I enjoy my life. & .889 \\
3. All in all, I am satisfied with my life. & .804 \\
4. In general, I am confident. & .743 \\
5. I manage well to fulfil my needs. & .817 \\
6. I am in good physical and emotional condition. & .865 \\
7. I feel that I am actually well equipped to deal with life and its difficulties. & .813 \\
8. Much of what I do brings me joy. & .825 \\
9. I am a calm, balanced human being. & .512 \\
\hline Explained Variance & 48.466 \\
Eigenvalue & 4.362 \\
\hline
\end{tabular}

\section{Confirmatory Factor Analysis (CFA)}

Confirmatory Factor Analysis is an analysis method used for the confirmation of a previously specified structure as a model (Büyüköztürk, 2002). In this study, CFA was used for determining if the singlefactor structure of the PMHS would be confirmed in a sample group of Turkish university students. During CFA, various goodness of fit indices were used to determine the correspondence of the model. For the reason that different indices have different strengths and weaknesses against each other, it is suggested to execute different indices in evaluating the fitness of the scale (Büyüköztürk, Akgün, Özkahveci, \& Demirel, 2004).

In the first step of the recent study, for the evaluation of the single-factor model structured for the Positive Mental Health Scale; ratio of $\chi^{2}$ to the degree of freedom was used. This value, being lower than 5 , implies that its fitness is at acceptable level (Kline, 2005). Comparative Fit Index (CFI), Incremental Fit Index (IFI), Relative Fit Index (RFI), Normed Fit Index (NFI) and Non-Normed Fit Index approximate to the value of 1 according to its fitness level to the model. These index values being higher than .95 implies good fitness, while the values fall between .90 and .94 are considered as acceptable fitness values. The Root Mean Square Error of Approximation (RMSEA) value being lower than .05 implies good fit, while the value between $.06-.08$ is acceptable fit and RMSEA value lower than .10 is perceived as poor fit (Hu \& Bentler, 1999; Kline, 2005; Tabachnick \& Fidell, 2001). 
Table 2.

The Goodness of Fit Results Concerning the Confirmatory Factor Analysis

\begin{tabular}{ccccccccccc}
\hline & $\chi^{2}$ & sd & $\chi^{2} / \mathrm{sd}$ & RMSEA & CFI & NFI & NNFI & GFI & IFI & RFI \\
\hline Single-Factor Model & 133.76 & 27 & 4.95 & .11 & .95 & .94 & .94 & .92 & .95 & .92 \\
\hline
\end{tabular}

According to Table $2, \chi^{2} / \mathrm{sd}$ value for this model was 4.95 . Considering that, the calculated value was lower that the specified standard, the fitness level concerning the model was treated as acceptable. It was also indicated that there occurs a poor fit for RMSEA index and generally good fit for the indices of CFI, NFI, IFI, NNFI, RFI and GFI. In conclusion; this single-factor model that was structured for the study was believed to be in good fit for Turkish culture. Standardized loadings, $\mathrm{t}$-values and $\mathrm{R}^{2}$ values of scale items are presented in Table 3.

Table 3.

The Factor Loadings and Parameter Estimations Relevant to Confirmatory Factor Analysis

\begin{tabular}{lccc}
\hline Items & Standardized Loadings & t-values & $\mathrm{R}^{2}$ \\
\hline Item 1 & .55 & 11.96 & .45 \\
Item 2 & .37 & 10.33 & .63 \\
Item 3 & .52 & 11.75 & .48 \\
Item 4 & .69 & 12.60 & .31 \\
Item 5 & .60 & 12.19 & .40 \\
Item 6 & .42 & 10.90 & .58 \\
Item 7 & .63 & 12.35 & .37 \\
Item 8 & .52 & 11.77 & .48 \\
Item 9 & .89 & 13.17 & .11 \\
\hline
\end{tabular}

T-values given above in Table 3 were found to be meaningful at $p=.05$ level. Hence, all of the variables in the designed single-factor model were considered to have a statistically significant contribution to the model. As a result of the $\mathrm{R}^{2}$ values examination, it was found that the most contributing item for the latent variable of PMHS was the $2^{\text {nd }}$ item while the least contributing was $9^{\text {th }}$ item.

\section{Criterion-Related Validity Study}

Validity is not a psychometric feature to be examined through a single method. When examining the validity of any measuring instrument, it is suggested to repeat the process using various methods on different sampling groups and at different times (Kelecioğlu \& Göçer Şahin, 2014). Criterion-referenced 
validity of the scale was examined with this intention. In the study group including 360 university students; Oxford Happiness Questionnaire (OHQ), Psychological Well-Being Scale (PWBS) and The Brief Resilience Scale (BRS) was carried out along with Positive Mental Health Scale (PMHS). Through a concurrent validity study, relationship between these scales and the Positive Mental Health Scale (PMHS) was examined. The correlation values concerning the scales are given in Table 4.

Table 4.

Results Concerning the Criterion-Referenced Validity for Positive Mental Health Scale

\begin{tabular}{lllll}
\hline & & OHQ & PWBS & BRS \\
\hline \multirow{2}{*}{ PMHS } & Correlation & .77 & .72 & .48 \\
\cline { 2 - 5 } & $\mathrm{P}$ & .000 & .000 & .000 \\
\hline
\end{tabular}

PMHS: Positive Mental Health Scale, OHQ: Oxford Happiness Questionnaire, PWBS: Psychological Well-Being Scale, BRS: The Brief Resilience Scale

These results indicated a strong, meaningful and positive relationship between PWBS and OHQ $(r=.77$, $p<.05)$. Likewise, PWBS and PMHS also had strong, meaningful and positive relationship $(r=.72, p<$ .05). Finally, between BRS and PMHS, a moderate, meaningful and positive relationship was observed $(r$ $=.48, p<.05)$. The results was interpreted that adapted PMH scale was valid for the Turkish culture.

\section{Reliability}

Cronbach Alpha coefficient was calculated to examine the internal consistency coefficient of the PMHS, which is a nine-item and Likert-type scale. The coefficient value was .85. Reliability coefficient is affected by item count and reliability increases along with the number of items that measure same feature (Crocker \& Algina, 1986). Although the item count in this scale is low, a strong reliability was found. To specify the test-retest reliability score of the scale, form in Turkish language was implemented twice, once at the start and at the end of 21 days, to 80 university students receiving education at faculty of education. Collected findings indicated that the correlation coefficient was $.80(p<.001)$. These results implied that the scores collected from PMHS scale implementation to Turkish culture were able to be interpreted reliably.

\section{DISCUSSION}

In this study, adaptation of the Positive Mental Health Scale (PMHS), developed by Lukat et al. (2016) into Turkish language and examining the psychometric features of the Turkish form were aimed. The sample size was adequate in quantity to meet the needed criterion for statistical analyses. The findings collected as the result of this adaptation study, which implemented with the sample of university students, indicated that the scale was able to measure the positive mental health level in valid and reliable degree.

As the first step of the study; linguistic equivalency studies were carried out. Translation-retranslation method was used in the translation of PMHS. As a result of the translation studies, linguistic 
equivalency with the original form was achieved. In the next phase, exploratory and confirmatory factor analyses, criterion-referenced validity analysis and internal consistency analysis were carried out to evaluate the psychometric features of the scale.

According to Exploratory Factor Analysis, a single-factor structure that explained the $48.46 \%$ of the scale was designed. Considering that the explained variance ratio in scale development and adaptation researches needs to be $40 \%$ or above (Tabachnik \& Fidell, 1996), explained variance level in this study was accepted as adequate. To decide whether the single-factor structure of the original form was maintained, Confirmatory Factor Analysis was realized. Collected results from applied goodness of fit indices showed that the single-factor structure of the scale was maintained in the recent study that included the sample group of Turkish university students. Reliability of the scale was examined thorough the calculation of internal consistency coefficient. Once again, with 21 days apart, test-retest reliability study was applied. Obtained findings showed that the scale had high level of reliability.

During the examination of criterion-referenced validity; Oxford Happiness Questionnaire (OHQ), Psychological Well-Being Scale (PWBS) and The Brief Resilience Scale (BRS) were used. As expected, a meaningful and positive relationship between PMHS and OHQ was observed. PMHS and other measuring instruments, PWBS and BRS, also had positive and meaningful relationship as similar to other cultural adaptations of the scale.

This study was carried out with a sampling group including university students exclusively. Additionally, only healthy individuals were chosen as participants for the study. This might be perceived as one of the limitations of the study for the reason that the original study was used to evaluate the therapeutic effect and medical treatment on individuals who had been receiving help from clinics and counselling centres. Therefore, it will be meaningful for future studies to include individuals with any trauma, illness or stress disorder for examining psychometric features. It is also suggested to examine validity and reliability of the scale on different age groups.

In conclusion, Turkish form of the PMHS can be treated as a valid and reliable scale for measuring the mental health level of university students. Additionally this measuring instrument can be considered useful in areas of education, psychology and psychological counselling. Its applicability in short period of time and ease in utilisation and scoring as a scale, is considered to present an advantage. 


\section{REFERENCES}

Becker, P. (1989). Der trier persönlichkeits fragebogen (TPF) handan-weisung [The trier personality inventory (TIP) manual]. Göttingen, Germany: Hogrefe.

Büyüköztürk Ş. (2002). Faktör analizi: Temel kavramlar ve ölçek geliştirmede kullanımı. Kuram Ve Uygulamada Eğitim Yönetimi Dergisi, 8(32). Retrieved from: http://dergipark.gov.tr/download/article-file/108451

Büyüköztürk, Ş. (2004). Veri analizi el kitabı. Ankara: Pegem A Yayıncılık.

Büyüköztürk, Ş. Akgün, Ö. E., Özkahveci, Ö., \& Demirel, F. (2004). Güdülenme ve öğrenme stratejileri ölçeğinin Türkçe formunun geçerlik ve güvenirlik çalışması. Kuram Ve Uygulamada Eğitim Bilimleri, 4(2), 207-239. Retrieved from: https://toad.halileksi.net/olcek/gudulenme-veogrenme-stratejileri-olcegi

Crocker, L., \& Algina, J. (1986). Introduction to classical and modern test theory. Harcourt Brace Jovanovich College Publishers: Philadelphia.

Diener, E. D., Emmons, R. A., Larsen, R. J., \& Griffin, S. (1985). The satisfaction with life scale. Journal of Personality Assessment, 49, 71-75. Retrieved from: http://labs.psychology.illinois.edu/ ediener/Documents/Diener-Emmons-Larsen Griffin_1985.pdf

Diener, E. (2000). Subjective well-being. The science of happiness and a proposal for a national index. American Psychologist, 55(1), 34-43. doi: http://dx.doi.org/10.1037/0003-066X.55.1.34

Diener E., Wirtz, D., Biswas-Diener, R., Tov, W., Kim-Prieto, C., Choi, D., \& Oishi, S. (2009) New measures of well-being. In: Diener E. (Eds) Assessing well-being. Social Indicators Research Series, vol 39. Springer, Dordrecht. doi: https://doi.org/10.1007/978-90-481-2354-4_12

Diener, E., Wirtz, D., Tov, W., Kim-Prieto, C., Choi, D., Oishi, S., \& Biswas-Diener, R. (2010). New wellbeing measures: Short scales to assess flourishing and positive and negative feelings. Social Indicators Research, 97, 143-156. doi: https://doi.org/10.1007/s11205-009-9493-y

Doğan, T., \& Çötok, A. N. (2011). Oxford mutluluk ölçeği kısa formunun Türkçe uyarlaması: Geçerlik ve güvenirlik çalışması. Türk Psikolojik Danışma Ve Rehberlik Dergisi, 4, 165- 172. Retrieved from: http://pdrdergisi.org/index.php/pdr/article/view/100/101

Doğan, T. (2015). Kısa Psikolojik Sağlamlık Ölçeği'nin Türkçeye uyarlaması: geçerlik ve güvenirlik çalışması. The Journal of Happiness \& Well-Being, 3(1), 93-102. Retrieved from: http://www.journalofhappiness.net/frontend/articles/pdf/v03i01/77.pdf

Fahrenberg, J., Selg, H., \& Hampel, R. (1989). Das Freiburger Persön-lichkeitsinventar: FPI; Handanweisung; revidierte Fassung FPI-R und teilweise geanderte Fassung FPI-A1 [The Freiburg Personality Inventory: FPI; Manual; revised version FPI-R and partly adapted version FPI-A1]. Göttingen, Germany: Verlag für Psychologie Hogrefe.

Grob, A., Lüthi, R., Kaiser, F. G., Flammer, A., Mackinnon, A., \& Wearing, A. J. (1991). Berner Fragebogen zum Wohlbefinden Jugendlicher (BFW) [The Bern Subjective Well-Being Questionnaire for Adolescents (BFW)]. Diagnostica, 37, 66-75. Retrieved from: 
https://www.researchgate.net/publication/284662922_Berner_Fragebogen_zum_Wohlbefinde n_Jugendlicher_BFW

Hills, P., \& Argyle, M. (2002). The oxford happiness questionnaire: A compact scale for the measurement of psychological well-being. Personality and Individual Differences, 33, 1073-1082. doi: https://doi.org/10.1016/S0191-8869(01)00213-6

Hu, L., \& Bentler, P. M. (1999). Cut-of criteria for fit indices in covariance structure analysis: Conventional criteria versus new alternatives. Structer Equation Modeling, 6, 1-55. doi: https://doi.org/10.1080/10705519909540118

Hu, Y., Stewart-Brown, S., Twigg, L., \& Weich, S. (2007). Can the 12 item General Health Questionnaire be used to measure positive mental health? Psychological Medicine, 37(7), 1005-1013. doi: https://doi.org/10.1017/S0033291707009993

Kelecioğlu, H., \& Göçer Sahin, S. (2014). Geçmişten günümüze geçerlik. Eğitimde Ve Psikolojide Ölçme ve Değerlendirme Dergisi, 5(2). doi: https://doi.org/10.21031/epod.41706

Keyes, C. L. M., Shmotkin, D., \& Ryff, C. D. (2002). Optimizing well-being: The empirical encounter of two traditions. Journal of Personality and Social Psychology, 82(6), 1007-1022. doi: http://psycnet.apa.org/doi/10.1037/0022-3514.82.6.1007

Keyes, C. L. M. (2002). The mental health continuum: From languishing to flourishing in life. Journal of Health and Social Behavior, 43, 207-222. doi: http://dx.doi.org/10.2307/3090197

Kline, B. R. (2005). Principles and practice of structural equation modeling. New York: The Guilford Press.

Lovibond, P. F., \& Lovibond, S. H. (1995). The structure of negative emotional states: Comparison of the Depression Anxiety Stress Scales (DASS) with the Beck Depression and Anxiety Inventories. Behaviour Research and Therapy, 33, 335-343. doi: https://doi.org/10.1016/0005-7967(94)00075-U

Lukat, J., Margraf, J., Lutz, R., van der Veld, W. M., \& Becker, E. S. (2016). Psychometric properties of the Positive Mental Health Scale (PMH-scale). BMC Psychology, 4, 8. doi: https://doi.org/10.1186/s40359-016-0111-x

Lukat, J., Becker, E. S., Lavallee, K. L., Veld, W. M., \& Margraf, J. (2017). Predictors of incidence, remission and relapse of Axis I mental disorders in young women: a transdiagnostic approach. Clin. Psychol. Psychother., 24, 322-331. doi: https://doi.org/10.1002/cpp.2026

Maercker, A., Zhang, X.C.,Gao, Z., Kochetkov, Y., Lu, S., Sang, Z., ... Margraf, J. (2015). Personal value orientations mediated predictors of mental health: A three-culture study of Chinese, Russian, and German university students. International Journal of Clinical and Health Psychology, 15, 8-17. doi: https://doi.org/10.1016/j.ijchp.2014.06.001

Ryan, R. M., \& Deci, E. L. (2001). On happiness and human potential: A review of research on hedonic and eudaimonic well-being. Annual Review of Psychology, 52, 141-166. doi: http://dx.doi.org/10.1146/annurev.psych.52.1.141

Ryff, C. D. (1989). Happiness is everything, or is it? Explorations on the meaning of psychological wellbeing. Journal of Personality and Social Psychology, 57, 1069-1081. doi: http://dx.doi.org/10.1037/0022-3514.57.6.1069 
Ryff, C. D. (1995). Psychological well-being in adult life. Current Directions in Psychological Science, 4, 99104. doi: https://doi.org/10.1111\%2F1467-8721.ep10772395

Smith, B. W., Dalen, J., Wiggins, K., Tooley, E., Christopher, P., \& Jennifer Bernard, J. (2008). The brief resilience scale: Assessing the ability to bounce back. International Journal of Behavioral Medicine, 15, 194-200. doi: 10.1080/10705500802222972

Tabachnick B. G., \& Fidell, L. S. (2001). Using multivariate statistics. USA: Pearson Education Company.

Telef, B. B. (2013). Psikolojik İyi Oluş Ölçeği (PIOO): Türkçe'ye uyarlama: Geçerlik ve güvenirlik çalışması. Hacettepe Eğitim Fakültesi Dergisi, 28(3), 374-384. Retrieved from: http://www.efdergi.hacettepe.edu.tr/yonetim/icerik/makaleler/237-published.pdf

Tennant, R., Hiller, L., Fishwick, R., Platt, S., Joseph, S., Weich, S., ... Stewart-Brown, S. (2007). The Warwick-Edinburgh mental well-being scale (WEMWBS): Development and UK validation. Health and Quality of Life Outcomes, 5(1), 50-63. doi: https://doi.org/10.1186/1477-7525-5-63

Tönnies, S., Plöhn, S., \& Krippendorf, U. (1996). Skalen zur psychischen Gesundheit (SPG) [Scales for mental health (SPG)]. Heidelberg, Germany: Asanger.

Vaingankar, J. A., Subramaniam, M., Lim, Y. W., Sherbourne, C., Luo, N., Ryan, G., ... Chong. (2012). From well-being to positive mental health: Conceptualization and qualitative development of an instrument in Singapore. Quality of Life Research, 21, 1785-94. doi: http://dx.doi.org/10.1007/s11136-011-0105-3.

Waterman, A. S. (1993). Two conceptions of happiness: Contrasts of personal expressiveness (eudaimonia) and hedonic enjoyment. Journal of Personality and Social Psychology, 64, 678-691. doi: http://psycnet.apa.org/doi/10.1037/0022-3514.64.4.678

World Health Organization (2003). Investing in Mental Health. Retrieved from: http://www.who.int/mental_health/media/investing_mnh.pdf 